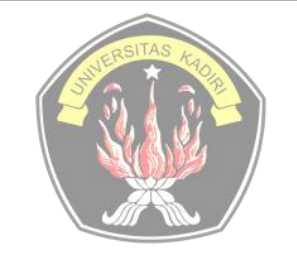

Tersedia online di

"http://ojs.unik-kediri.ac.id/index.php/ekonika"

http://dx.doi.org/10.30737/ekonika.v6i2.1447

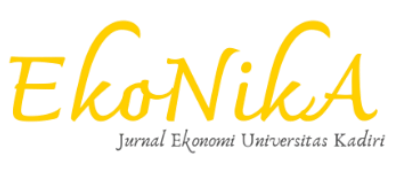

\title{
Pengaruh Online Review Dan Virtual Reality Terhadap Attitude Toward Destination Dan Intention To Visit Destination
}

\author{
Stefanus Alvin Hartono, S.Kom, Dr. Sri Hartini, SE.,M.Si. \\ 1,2Fakultas Ekonomi dan Bisnis Universitas Airlanggal \\ email:1stefanusalvinh@gmail.com, 2sri_hartini@feb.unair.ac.id
}

\section{Artikel History:}

Artikel masuk : 01-06-2021

Artikel revisi : 26-08-2021

Artikel diterima : 29-08-2021

\section{Keywords:}

online review, application of virtual reality, tourist

destinations, attitudes towards destinations, intention to visit destinations

\begin{abstract}
ABSTRAK
Penelitian ini bertujuan untuk memvalidasi efek online review dan pengalikasian virtual reality terhadap attitude toward destination dan memunculkan intention to visit destination. Pendekatan penelitian ini menggunakan kuantitatif dan pengumpulan data dengan metode survei. Teknik pengambilan sampel dalam penelitian ini menggunakan purposive sampling yang merupakan bagian dari nonprobability sampling. Sampel penelitian ini adalah konsumen yang aktif dalam aktivitas online dan dapat menggunakan website, dengan usia minimal 19 tahun sebanyak 160 sampel. Teknik analisis yang digunakan adalah analisis anova dan regresi. Hasil penelitian menunjukan bahwa online review dan pengaplikasian virtual reality berpengaruh positif terhadap attitude toward destination dan intention to visit destination. Kemudian online review positif dan negatif berpengaruh signifikan terhadap attitude toward destination dan intention to visit destination. Sedankan pengaplikasian virtual reality juga berpengaruh signifikan terhadap attitude toward destination dan intention to visit destination. Penelitian ini juga menunjukan jika tingkat attitude toward destination dalam mengunjungi wisata dapat memperkuat dan memperlemah intenion to visit destination. Dengan hasil tersebut, destinasi wisata sikap terhadap wisata yang dirasakan konsumen dapat memperkuat atau memperlemah niat untuk mengunjugi destinasi wisata
\end{abstract}

\section{ABSTRACT}

This study aims to validate the effect of online review and application of virtual reality on attitudes towards destinations and canceling intentions to visit destinations. The research approach uses quantitative data and data with survey methods. The sampling technique in this study used purposive sampling which is part of nonprobability sampling. The research sample is a consumer who is active in online activities and can use a website, with a minimum age of 19 years as many as 160 samples. The analysis technique used is anova analysis and regression. The results showed that online reviews and the application of virtual reality had a positive effect on attitudes towards destinations and intention to visit destinations. Then online positive and negative reviews have a significant effect on 
attitudes towards destinations and intention to visit destinations. Meanwhile, the application of virtual reality also has a significant effect on attitudes towards destinations and intention to visit destinations. This research also shows that the level attitude towards the purpose of visiting tourism can review and weaken the intention to visit the destination. With these results, the perceived attitude of tourist destinations towards tourism can assess or weaken the intention to visit tourist destinations

\section{INTRODUCTION}

Teknologi Virtual Reality (VR) adalah suatu teknologi yang dapat mensimulasikan lingkungan yang sangat realistis (Bohil et al., 2011). Teknologi generasi terbaru menawarkan pengalaman yang lebih menyenangkan, jelas, dan mendalam, menghadirkan rasa kehadiran di dunia virtual (Waterworth et al., 2015). VR mengabstraksi para pengguna dari lingkungan sekitarnya dan memberi mereka rangsangan visual dan audio untuk membuat mereka merasa dalam pengaturan atau kehadiran yang sama sekali berbeda (telepresence) (Ali, 2016; Hyun \& O’Keefe, 2012).

Virtual reality, sering disebut sebagai lingkungan virtual, adalah teknologi komputer yang memungkinkan pengguna untuk melihat atau 'membenamkan diri' dalam dunia alternatif. Melalui penggunaan grafik komputer real-time, pengguna mengalami lingkungan yang dihasilkan komputer seolah-olah itu nyata dan mereka adalah bagian darinya. Dengan demikian, pengguna dapat berjalan di permukaan Mars, menerbangkan pesawat, atau berjalanjalan melalui Kapel Sistine tanpa benar-benar berada di sana. Virtual reality, meskipun teknologinya tidak dilabeli seperti itu, dimulai pada 1960-an ketika Morton Heilig menemukan Sensorama Simulator. Simulator ini adalah teater satu orang dengan video tiga dimensi (3D), suara stereo, aroma, angin, dan kursi bergetar (Iachini et al., 2019).

Semakin banyak pengecer menggunakan visualisasi produk 3D interaktif untuk pelanggan online karena perangkat virtual reality (VR) menjadi lebih mudah diakses, membuka kemungkinan untuk cara baru belanja secara virtual. Namun, skeptis mempertanyakan efektivitas relatif menggunakan 3D VR untuk belanja online. Studi yang meneliti dampak VR 3D pada hasil pembelian tidak konsisten (H. Li et al., 2002; Suh \& Lee, 2005) dan lebih jauh menunjukkan bahwa 3D VR tidak menghasilkan efek peningkatan pada niat pembelian bila dibandingkan dengan media 2D konvensional (H. Li et al., 2002).

VR menyediakan lingkungan dimana pengguna dapat mengambil informasi dalam modalitas multi-sensorik, termasuk visual, auditori, dan kinestetik, memungkinkan pengguna untuk merasakan representasi realistis dari lingkungan yang digambarkannya (Slater \& Usoh, 1993). Persepsi ini mengarah pada rasa "hadir" dalam atau "dibawa" ke lingkungan virtual (Lombard \& Ditton, 1997; Schuemie et al., 2001; Slater, 1999; Zahorik \& Jenison, 1998). Inti 

dari pengalaman perjalanan dan pariwisata adalah perjumpaan turis dengan lingkungan tujuan, "realitas" orang lain. Wisatawan tergoda oleh daya pikat tempat dan pemandangan; beberapa terutama didorong oleh keinginan untuk mengalami sensasi visual dari wilayah yang jauh (Steenjacobsen, 2001), yang lain oleh makna yang lebih dalam dibelakang berinteraksi dengan aspek sosiokultural tujuan wisata (Gibson, 2009). Zahorik dan Jenison (1998), berhasil membuktikan bahwa jalan-jalan di destinasi wisata virtual akan mengarahkan pengguna untuk merasakan rasa kehadiran, dirinya sebagai berada di tujuan. Akibatnya, kehadiran menjelaskan keefektifan VR sebagai pengganti dan / atau simulasi perjalanan. Secara teoritis, meneliti pengalaman VR dalam pariwisata akan memberikan pemahaman yang lebih baik tentang kehadiran dalam pengalaman VR yang melibatkan penggambaran virtual lingkungan nyata, dimana tindakan yang mungkin, seperti navigasi dan tamasya, menyerupai (sering kali tidak dapat dibedakan dari) konsumsi aktual pengalaman VR membentuk sikap terhadap konsumsi aktual (Tussyadiah et al., 2018).

Online Consumer Review (OCR) adalah bentuk khusus dari kata elektronik dari mulut ke mulut (eWOM) yang biasanya berisi saran, pendapat, dan komentar dari konsumen lain; OCR juga biasanya dianggap tidak memihak dan dapat dipercaya. Dalam beberapa tahun terakhir OCR telah menjadi sumber utama informasi yang memungkinkan konsumen mencari dan menemukan produk yang sesuai dengan preferensi mereka dan untuk membuat keputusan pembelian yang lebih baik (Chen \& Xie, 2008; Ye et al., 2011). Penelitian telah menunjukkan bahwa, ketika membuat keputusan pembelian, $85 \%$ konsumen memercayai online review sebanyak rekomendasi pribadi (BrightLocal, 2017). Dengan demikian, banyak perusahaan menempatkan OCR di situs web mereka untuk memotivasi konsumen untuk secara aktif berkolaborasi dengan mereka dan untuk mempromosikan berbagai jenis interaksi (Shi \& Liao, 2017).

Terdapat dua tipe eWOM yaitu review positif dan negatif yang dapat berpengaruh terhadap niat pembelian. Praktisi pemasaran dan peneliti telah mengeksplorasi aspek OCR yang penting untuk meningkatkan efektivitasnya, valensi pesan menjadi salah satu yang paling sering dipelajari. Adalah logis untuk berpikir bahwa OCR dengan valensi positif akan memiliki pengaruh positif pada aspek-aspek seperti persepsi manfaat, kepuasan, dan niat beli. Faktanya, sebagian besar penelitian empiris telah menemukan hubungan linear positif antara valensi OCR positif dan negatif terhadap niat pembelian (mis., (Moe et al., 2011; Pan \& Chiou, 2011; Tsao et al., 2015)). Online review telah menarik perhatian penelitian dalam beberapa tahun terakhir. Penelitian yang ada berfokus pada efek valensi ulasan karena ulasan positif dan negatif adalah bentuk rekomendasi yang paling sering diamati (Arndt, 1967). Namun, hasil sebelumnya tidak memberikan kesimpulan yang jelas. Beberapa penelitian menunjukkan bahwa efek positif 
terjadi (Clemons et al., 2006; Gershoff et al., 2003; M. Lee \& Youn, 2009; Skowronski \& Carlston, 1989), yang lain menunjukkan efek negatif (Fiske, 1980; M. Lee \& Youn, 2009; J. Yang \& Mai, 2010) dan beberapa lainnya berpendapat bahwa ulasan valensi tidak menghasilkan efek diferensial (Cheung et al., 2009; Doh \& Hwang, 2009).

Menurut Paivio (1990) berpendapat online review dan virtual reality adalah dua jenis informasi yang berbeda. Online review biasanya dalam bentuk teks, beberapa dalam kombinasi dengan gambar atau video. Sebaliknya, informasi dalam virtual reality adalah visual dan sensorik. Teori pengkodean ganda menunjukkan bahwa orang memiliki dua sistem mental yang terpisah dalam memproses berbagai jenis informasi: satu menangani pesan verbal dan yang lainnya non-verbal seperti gambar visual. Dengan demikian, dua sistem mental berfungsi secara berbeda: informasi verbal sering diterima, diubah menjadi representasi mental, dan disimpan dalam memori secara berurutan, sedangkan untuk informasi non-verbal, aktivitas ini dilakukan secara bersamaan (Holbrook dan Moore 1981; Paivio 1990). Memproses informasi teks sering kali agak lambat dan melelahkan, dan memiliki permintaan tinggi pada sumber daya kognitif, sementara memproses informasi non-verbal cukup intuitif, dengan permintaan relatif lebih sedikit pada sumber daya kognitif (Pieters dan Wedel 2004) dan lebih mudah untuk membentuk pencitraan mental (Bogicevic et al., 2019).

Karena ulasan online ini ditulis oleh konsumen, pemirsa menganggap informasi ini lebih baik dan dapat dipercaya daripada informasi dari pemasar (M. Anderson, 2013; Bickart \& Schindler, 2001; J. Brown et al., 2007; Zhang et al., 2010). Akibatnya, bagaimana ulasan online memengaruhi sikap konsumen menjadi sangat menarik bagi peneliti dan praktisi. Sikap, ditentukan oleh sekumpulan keyakinan yang menonjol tentang objek, dapat berubah; itu mungkin diperkuat, dilemahkan atau diganti dengan keyakinan baru (Fishbein \& Ajzen, 1975). Perubahan sikap berarti bahwa evaluasi individu dimodifikasi dari satu nilai ke nilai lain dan perubahan biasanya dinilai relatif terhadap sikap awal individu (Petty, 2012). Informasi yang diperoleh setelah pengalaman konsumsi dapat memengaruhi penilaian konsumen melalui proses pemutakhiran keyakinan (Hoch \& Ha, 1986; Smith, 1993) dan mengubah memori pengalaman itu (Braun, 1999; Loftus, 2004). Dalam studi ini, menggunakan teknik yang sama dengan penelitian S. H. Lee \& Ro (2016), menguji pengaruh review valensi (positif dan negatif) terhadap perubahan sikap terhadap destinasi wisata. Studi ini berkontribusi pada literatur perilaku konsumen online dengan memeriksa pengaruh ulasan online pada pengalaman pasca perubahan sikap konsumen. Penelitian ini mengusulkan bahwa meskipun konsumen telah membentuk sikap berdasarkan pengalamannya sendiri, keyakinan baru seseorang dan evaluasi yang dimodifikasi dapat diperoleh dari ulasan dari konsumen lain di situs web online. Dalam proses ini, sikap mereka awalnya terbentuk dari pengalamannya sendiri dan berubah karena 

pendapat orang lain. Misalnya, seorang konsumen yang pernah berkunjung ke destinasi wisata di masa lalu dapat mengunjungi situs ulasan online, menemukan ulasan orang lain di destinasi wisata yang sama, dan membandingkan opini tersebut dengan opini mereka.

Penelitian sebelumnya menunjukkan bahwa ulasan online memengaruhi sikap konsumen dan perilaku pembelian (Sparks dan Browning, 2011; Tsao et al., 2015; Vermeulen dan Seegers, 2009; Zhang et al., 2010). Asumsi umum yang mendasari penelitian yang menyelidiki dampak ulasan online pada sikap adalah bahwa mereka yang membaca ulasan adalah calon konsumen tanpa pengalaman konsumsi produk atau layanan sebelumnya (Mauri dan Minazzi, 2013; Zhang et al., 2010). Beberapa studi mengenai konten ulasan berpendapat bahwa ulasan berbasis atribut lebih informatif daripada yang berbasis pengalaman (Park et al., 2007) karena ulasan berbasis atribut memberikan informasi yang dikaitkan lebih spesifik dan jelas dan menjelaskan alasan klaim ini, sementara pengalaman produk mungkin berbeda diantara individu. Studi lain menunjukkan bahwa ulasan berbasis pengalaman dapat membantu konsumen mendapatkan pengalaman produk tidak langsung dengan merasakan sikap dan emosi konsumen lain (Bei et al., 2004). Studi menunjukkan bahwa VR sebagai alat pemasaran pariwisata yang kuat (G. Brown, 2006; A. Williams, 2006; P. Williams \& Hobson, 1995) karena mampu menawarkan citra yang lebih menarik dari tujuan wisata kepada calon wisatawan dengan memberi mereka rasa apa rasanya seperti berada di sana, yaitu adalah pengalaman "mencoba sebelum membeli."

Semakin banyak jumlah format iklan dapat menimbulkan efek yang bervariasi pada dua aspek tersebut. Pertama, cara konsumen merespon iklan. Kedua, cara iklan tersebut memungkinkan untuk memengaruhi konsumen (Tutaj \& van Reijmersdal, 2012). Konsumen tidak menyadari bahwa tujuan dari iklan tersebut adalah untuk membujuk mereka untuk membeli produk atau jasa tertentu (John, 1999). Penggunaan virtual reality banyak digunakan untuk pemasaran pada industri pariwisata. Virtual reality diharapkan akan meningkatkan kunjungan pada destinasi wisata. Konsumen yang memiliki kesan ketika menggunakan virtual reality pada suatu destinasi diharapkan meningkatkan niat wisatawan untuk mengunjungi destinasi wisata tersebut. Niat berkunjung wisatawan ditentukan attitude atas tempat wisata. Attitude merupakan prediksi kuat dalam menentukan perilaku konsumen terkait keputusan pembelian. Penggunaan virtual reality sebagai media promosi, diharapkan akan meningkatkan atittude konsumen atas destinasi wisata (Hartini et al., 2020).

Studi yang ada telah menemukan bahwa VR berkontribusi pada niat membeli pelanggan (misalnya Suh \& Chang, 2006; Van Kerrebroeck et al., 2017). Namun, beberapa penelitian telah secara langsung meneliti efek VR pada pemasaran pariwisata (Guttentag, 2010). Misalnya, Marasco et al. (2018) dan Tussyadiah et al. (2018) menemukan bahwa pengalaman 
VR berpengaruh positif terhadap perubahan sikap wisatawan dan niat berkunjung. Seperti yang dinyatakan Y. C. Huang et al. (2013), diteliti prediktor yang dapat memengaruhi niat perjalanan wisatawan dalam pengalaman virtual. Menurut teori motivasi, niat perilaku seseorang dipengaruhi oleh motivasi ekstrinsik dan intrinsik mereka (misalnya Hwang et al., 2018; Ryan $\&$ Deci, 2000).

Penelitian ini bertujuan untuk memvalidasi efek positif dan negatif review terhadap keinginan untuk mengunjungi destinasi wisata pada jasa tourism dan pengalikasian VR serta attitude toward destination sehingga memunculkan intention to visit destination. Namun masih sedikit literatur yang membahas VR yang memengaruhi intention to visit destination dan attitude toward destination. Masih terbatasnya penggunaan VR pada penjualan jasa di Indonesia. Karena itu penelitian ini penting untuk dilakukan agar dapat mengetahui efek positif dan negatif review terhadap intention to visit destination dengan pengaplikasian VR. Diharapkan dengan adanya penelitian ini membantu pemasaran dengan menggunakan metode VR untuk penjualan. Diharapkan juga penelitian ini dapat menjadi referensi para peneliti kedepan untuk mengembangkan teknik penyampaian pesan yang lebih efektif.

\section{LITERATURE REVIEW}

Penelitian yang dilakukan oleh Zeng et al., (2020) berjudul "When online reviews meet virtual reality: Effects on consumer hotel booking" studi ini meneliti efek langsung dan interaksi online review (kualitas dan kuantitas) dan virtual reality pada pemesanan hotel konsumen. Data dikumpulkan dari dua studi eksperimen $2 \times 2$. Hasil menunjukkan efek langsung dari tinjauan online dan aplikasi virtual reality pada niat perilaku, dan pengaruh online review pada niat perilaku melemah ketika virtual reality diterapkan. Selain itu, online review dan virtual reality memiliki efek gabungan yang signifikan pada niat perilaku, dengan kekuatan yang lebih besar daripada online review sendiri. Temuan ini memberikan wawasan untuk manajer perjalanan dan pariwisata untuk meningkatkan efek komunikasi pemasaran dengan menggunakan virtual reality yang tepat untuk melengkapi online review. Persamaan penelitian ini dengan penelitian sebelumnya yang telah dilakukan oleh Zeng et al., (2020) terletak pada variabel online reviews kepada purchase intention dengan dimoderasi oleh pengaplikasian virtual reality, terpadat perbedaan pada penelitian ini sebelumnya, dimana penelitian ini menggunakan online reviews kualitas dan kuantitas tetapi pada penelitian ini menggunakan positive reviews dan negative reviews. Terdapat juga perbedaan pada penelitian ini menggunakan attitude toward destination dan pengaplikasian $V R$ pada intention to visit destination. Penelitian ini juga mendapatkan inspirasi dari Hu \& Kim, (2018) terletak pada 

pemilihan positive dan negative eWOM, persamaan lainnya terletak pada penelitian $\mathrm{Hu} \& \mathrm{Kim}$, (2018) dalam penelitian ini berfokus pada pengaplikasian virtual reality. Persamaan lainnya penelitian fokus pada positive dan negative eWOM. Terdapat perbedaan yaitu, pada variabel eWOM behavior akan diganti oleh variabel intention to visit destination.

Gambar 1. Kerangka Konsep Penelitian

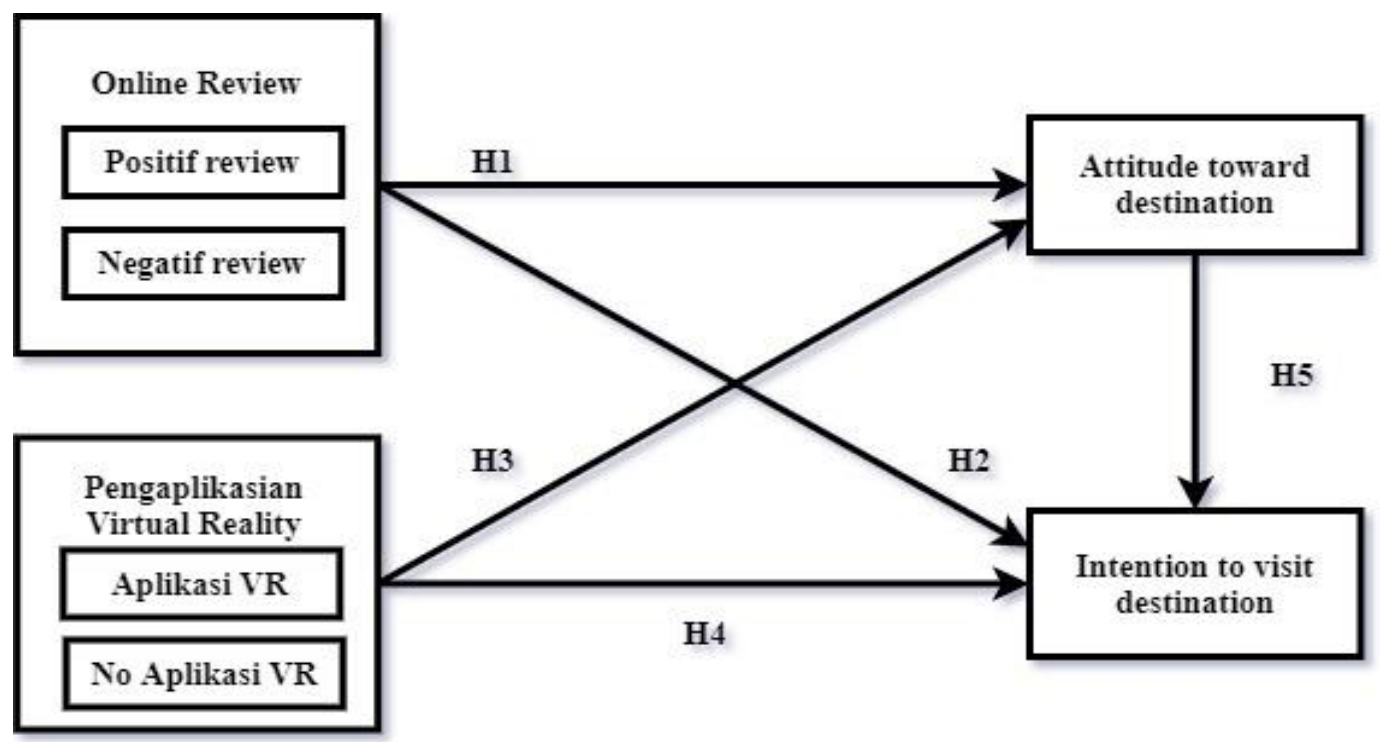

\section{METHODS}

Pendekatan penelitian ini menggunakan kuantitatif dan pengumpulan data dengan metode survey. Penelitian ini menggunakan data primer yang diambil dari jawaban responden melalui pengisian kuisonair yang disebarkan secara online sesuai dengan item-item setiap variabel. Teknik sampling pada penelitian ini menggunakan purposive sampling yang termasuk bagian dari nonprobability sampling. Variabel eksogen diantaranya online reviews, pengaplikasian virtual reality, sedangkan variabel endogen attitude toward destination dan intention to visit destination Penelitian ini menggunakan metode kuantitatif yang menitikberatkan pada pengujian dan pembuktian hipotesis melalui pengumpulan data. Pendekatan kuantitatif adalah pendekatan yang menggunakan angka statistik untuk membantu menjelaskan, mendeskripsikan, dan menjawab permasalahan dalam penelitian (D. Coates et al., 1992). Dalam pendekatan kuantitatif, dilakukan pengujian teori dengan cara mengukur variabel penelitian dengan menggunakan prosedur statistik (Hartono, 2015). Bila dilihat dari tujuannya, penelitian ini termasuk ke dalam penelitian kausalitas. Penelitian kausalitas bertujuan untuk memahami variabel manakah yang termasuk ke dalam variabel independen (yang memengaruhi) dan variabel manakah yang merupakan variabel dependen (yang dipengaruhi) dari suatu fenomena tertentu (Malhotra, 2009). Dalam pelaksanaannya, penelitian ini 
menggunakan metode eksperimen. Penelitian eksperimen dilakukan dengan cara memanipulasi satu variabel bebas dan mengukur pengaruhnya pada satu atau lebih variabel terikat dengan mengontrol penuh variabel pengganggu (Malhotra, 2009). Penelitian eksperimen ini menggunakan Jakarta Aquarium sebagai objek penelitian dan dilakukan dengan manipulasi terhadap online review dan pengaplikasian virtual reality serta mengukur pengaruhnya terhadap attitude toward destination dan intention to visit destination. Sampel dari penelitian ini adalah mahasiswa aktif yang dapat menggunakan website untuk mencari destinasi wisata, dengan usia minimum 19 tahun. Ukuran sampel yaitu berjumlah 160 sampel. Tehnik analisis yang digunakan adalah Anova dan Regresi.

\section{RESULTS}

Responden pada penelitian ini berjumlah 160 orang. Sebagian besar responden adalah perempuan, usia 19 - 24 tahun. pendidikan sarjana, dan pengguna website aktif. Jawaban responden pada variabel penelitian dapat dilihat pada Tabel berikut :

Tabel 1. Persepsi Responden pada Variabel Attitude Toward Destination

\begin{tabular}{|c|c|c|c|c|c|c|c|c|}
\hline \multirow{2}{*}{$\begin{array}{l}\text { Online } \\
\text { Review }\end{array}$} & \multirow{2}{*}{$\begin{array}{l}\text { Virtual } \\
\text { Reality }\end{array}$} & \multirow{2}{*}{ Indikator } & \multicolumn{5}{|c|}{ Attitude Toward Destination } & \multirow{2}{*}{ Rata-Rat } \\
\hline & & & ATT.1 & ATT.2 & ATT.3 & ATT.4 & ATT.5 & \\
\hline \multirow{12}{*}{ Negatif } & \multirow{6}{*}{$\begin{array}{c}\text { Non- } \\
\text { Virtual } \\
\text { Reality }\end{array}$} & STS & 37 & 37 & 37 & 37 & 36 & \multirow{6}{*}{1,085} \\
\hline & & $\mathrm{TS}$ & 3 & 2 & 3 & 3 & 4 & \\
\hline & & $\mathrm{N}$ & 0 & 1 & 0 & 0 & 0 & \\
\hline & & $S$ & 0 & 0 & 0 & 0 & 0 & \\
\hline & & SS & 0 & 0 & 0 & 0 & 0 & \\
\hline & & Rata-Rata & 1,075 & 1,1 & 1,075 & 1,075 & 1,1 & \\
\hline & \multirow{6}{*}{$\begin{array}{l}\text { Virtual } \\
\text { Reality }\end{array}$} & STS & 9 & 29 & 27 & 31 & 31 & \multirow{6}{*}{1,37} \\
\hline & & $\mathrm{TS}$ & 31 & 11 & 13 & 8 & 9 & \\
\hline & & $\mathrm{N}$ & 0 & 0 & 0 & 1 & 0 & \\
\hline & & $S$ & 0 & 0 & 0 & 0 & 0 & \\
\hline & & SS & 0 & 0 & 0 & 0 & 0 & \\
\hline & & Rata-Rata & 1,775 & 1,275 & 1,325 & 1,25 & 1,225 & \\
\hline \multirow{12}{*}{ Positif } & \multirow{7}{*}{$\begin{array}{c}\text { Non- } \\
\text { Virtual } \\
\text { Reality }\end{array}$} & STS & 0 & 0 & 0 & 0 & 0 & \multirow{6}{*}{4,435} \\
\hline & & TS & 0 & 0 & 0 & 0 & 0 & \\
\hline & & $\mathrm{N}$ & 0 & 0 & 0 & 0 & 0 & \\
\hline & & $S$ & 25 & 21 & 23 & 21 & 23 & \\
\hline & & SS & 15 & 19 & 17 & 19 & 17 & \\
\hline & & Rata-Rata & 4,375 & 4,475 & 4,425 & 4,475 & 4,425 & \\
\hline & & STS & 0 & 0 & 0 & 0 & 0 & \multirow{6}{*}{4,93} \\
\hline & \multirow{5}{*}{$\begin{array}{l}\text { Virtual } \\
\text { Reality }\end{array}$} & $\mathrm{TS}$ & 0 & 0 & 0 & 0 & 0 & \\
\hline & & $\mathrm{N}$ & 0 & 0 & 0 & 0 & 1 & \\
\hline & & $\mathrm{S}$ & 3 & 4 & 2 & 3 & 0 & \\
\hline & & SS & 37 & 36 & 38 & 37 & 39 & \\
\hline & & Rata-Rata & 4,925 & 4,9 & 4,95 & 4,925 & 4,95 & \\
\hline
\end{tabular}

Sumber : data diolah 
Berdasarkan hasil data di atas diketahui bahwa tanggapan responden pada kelompok 1 yaitu partisipan yang diberi stimuli online review yang negatif dan iklan destinasi tidak dengan pengaplikasian VR terhadap variabel Attitude Toward Destination menghasilkan rata-rata sebesar 1,085 yang artinya bahwa responden dalam kategori ini memiliki persepsi sikap terhadap Jakarta aquarium dengan nilai sangat tidak baik. Kemudian tanggapan responden pada kelompok 2 yaitu partisipan yang diberi stimuli online review yang negatif dan iklan destinasi dengan pengaplikasian VR terhadap variabel attitude toward destination menghasilkan ratarata sebesar 1,37 yang artinya bahwa responden dalam kategori ini memiliki persepsi sikap terhadap Jakarta Aquarium dengan nilai sangat tidak baik. Selanjutnya tanggapan responden pada kelompok 3 yaitu partisipan yang diberi stimuli online review yang positif dan iklan destinasi tidak dengan pengaplikasian VR terhadap variabel attitude toward destination menghasilkan rata-rata sebesar 4,435 yang artinya bahwa responden dalam kategori ini memiliki persepsi sikap terhadap Jakarta aquarium dengan nilai sangat baik. Berikutnya tanggapan responden pada kelompok 4 yang diberi stimuli online review yang positif dan iklan destinasi dengan pengaplikasian VR terhadap variabel attitude toward destination menghasilkan rata-rata sebesar 4,93 yang artinya bahwa responden dalam kategori ini memiliki persepsi sikap terhadap Jakarta Aquarium dengan nilai sangat baik. Dengan demikian dapat dinyatakan bahwa positive review dan penggunaan virtual reality mampu membentuk attitude toward destination terhadap Jakarta Aquarium dengan lebih baik. Dibuktikan dengan hasil ratarata pada kelompok positive review dan penggunaan virtual reality yang paling tinggi.

Tabel 2 Persepsi Responden pada Variabel Intention to Visit Destination

\begin{tabular}{|c|c|c|c|c|c|c|c|c|}
\hline \multirow{2}{*}{$\begin{array}{l}\text { Online } \\
\text { Review }\end{array}$} & \multirow{2}{*}{$\begin{array}{l}\text { Virtual } \\
\text { Reality }\end{array}$} & \multirow{2}{*}{ Indikator } & \multicolumn{5}{|c|}{ Intention to Visit Destination } & \multirow{2}{*}{$\begin{array}{l}\text { Rata- } \\
\text { Rata }\end{array}$} \\
\hline & & & IN.1 & IN.2 & IN.3 & IN.4 & IN.5 & \\
\hline \multirow{12}{*}{ Negatif } & \multirow{5}{*}{$\begin{array}{c}\text { Non } \\
\text { Virtual } \\
\text { Reality }\end{array}$} & STS & 37 & 36 & 37 & 37 & 37 & \multirow{6}{*}{1,11} \\
\hline & & $\mathrm{TS}$ & 3 & 3 & 2 & 1 & 1 & \\
\hline & & $\mathrm{N}$ & 0 & 1 & 1 & 2 & 2 & \\
\hline & & $\mathrm{S}$ & 0 & 0 & 0 & 0 & 0 & \\
\hline & & SS & 0 & 0 & 0 & 0 & 0 & \\
\hline & & Rata-Rata & 1,075 & 1,125 & 1,1 & 1,125 & 1,125 & \\
\hline & \multirow{6}{*}{$\begin{array}{l}\text { Virtual } \\
\text { Reality }\end{array}$} & STS & 28 & 20 & 29 & 32 & 31 & \multirow{6}{*}{1,31} \\
\hline & & TS & 12 & 20 & 10 & 7 & 9 & \\
\hline & & $\mathrm{N}$ & 0 & 0 & 1 & 1 & 0 & \\
\hline & & $\mathrm{S}$ & 0 & 0 & 0 & 0 & 0 & \\
\hline & & SS & 0 & 0 & 0 & 0 & 0 & \\
\hline & & Rata-Rata & 1,3 & 1,5 & 1,3 & 1,225 & 1,225 & \\
\hline \multirow{8}{*}{ Positif } & \multirow{6}{*}{$\begin{array}{c}\text { Non } \\
\text { Virtual } \\
\text { Reality }\end{array}$} & STS & 0 & 0 & 0 & 0 & 0 & \multirow{6}{*}{4,535} \\
\hline & & $\mathrm{TS}$ & 0 & 0 & 0 & 0 & 0 & \\
\hline & & $\mathrm{N}$ & 0 & 0 & 0 & 0 & 0 & \\
\hline & & $\mathrm{S}$ & 20 & 17 & 19 & 17 & 20 & \\
\hline & & SS & 20 & 23 & 21 & 23 & 20 & \\
\hline & & Rata-Rata & 4,5 & 4,575 & 4,525 & 4,575 & 4,5 & \\
\hline & Virtual & STS & 0 & 0 & 0 & 0 & 0 & \multirow{2}{*}{4,95} \\
\hline & Reality & $\mathrm{TS}$ & 0 & 0 & 0 & 0 & 0 & \\
\hline
\end{tabular}

Pengaruh Online Review dan Virtual Reality Terhadap Attitude Toward Destination dan Intention to Visit Destination 


\begin{tabular}{llccccccc}
\hline Online & Virtual & \multirow{2}{*}{ Indikator } & \multicolumn{5}{c}{ Intention to Visit Destination } & \multirow{2}{*}{ Rata- } \\
\cline { 3 - 7 } & Reality & & IN.1 & IN.2 & IN.3 & IN.4 & IN.5 & Rata \\
\cline { 3 - 7 } & $\mathrm{N}$ & 0 & 1 & 0 & 0 & 0 \\
& $\mathrm{~S}$ & 1 & 2 & 2 & 2 & 1 \\
& $\mathrm{SS}$ & 39 & 37 & 38 & 38 & 39 \\
& & Rata-Rata & 4,975 & 4,9 & 4,95 & 4,95 & 4,975 & \\
\hline
\end{tabular}

Sumber : data diolah

Berdasarkan hasil data di atas diketahui bahwa tanggapan responden pada kelompok 1 yang diberi stimuli online review yang negatif dan iklan destinasi tidak dengan pengaplikasian VR terhadap variabel intention to visit destination menghasilkan rata-rata sebesar 1,11 yang artinya bahwa responden dalam kategori ini memiliki persepsi sangat kecil kemungkinan untuk mengunjungi Jakarta Aquarium pada masa depan. Kemudian tanggapan responden pada kelompok 2 yang diberi stimuli online review yang negatif dan iklan destinasi dengan pengaplikasian VR terhadap variabel intention to visit destination menghasilkan rata-rata sebesar 1,31 yang artinya bahwa responden dalam kategori ini memiliki persepsi sangat kecil kemungkinan untuk mengunjungi Jakarta Aquarium pada masa depan. Selanjutnya tanggapan responden pada kelompok 3 yang diberi stimuli online review yang positif dan tidak pengaplikasian VR terhadap variabel intention to visit destination menghasilkan rata-rata sebesar 4,535 yang artinya bahwa responden dalam kategori ini memiliki persepsi sangat besar kemungkinan untuk mengunjungi Jakarta Aquarium pada masa depan. Berikutnya tanggapan responden pada kelompok 4 yang diberi stimuli online review yang positif dan dengan pengaplikasian VR terhadap variabel intention to visit destination menghasilkan rata-rata sebesar 4,95 yang artinya bahwa responden dalam kategori ini memiliki persepsi sangat besar kemungkinan untuk mengunjungi Jakarta Aquarium pada masa depan. Dengan demikian dapat dinyatakan bahwa online review yang positif dan penggunaan virtual reality mampu memperbesar kemungkinan untuk mengunjungi Jakarta Aquarium pada masa depan. Dibuktikan dengan hasil rata-rata yang paling tinggi pada presepsi responden.

\begin{tabular}{cccc}
\hline Variabel Independen & Variabel Dependen & Mean & Std. Deviation \\
\hline \multirow{2}{*}{ Attitude Toward } & Negatif & 1,2275 & 0,34236 \\
Destination & Positif & 4,6825 & 0,44174 \\
& Non-VR & 2,7600 & 1,72675 \\
& VR & 3,1500 & 1,81596 \\
& Negatif & 1,2100 & 0,37097 \\
Intention To Visit & Positif & 4,7425 & 0,40900 \\
Destination & Non-VR & 2,8225 & 1,77207 \\
& VR & 3,1300 & 1,85339 \\
\hline
\end{tabular}

Sumber : data diolah

Pengujian pengaruh online review (positif dan negatif) dan virtual reality (pengaplikasian VR dan tidak pengaplikasian VR) terhadap attitude toward destination dan intention to visit destination dilakukan menggunakan uji ANOVA. Kriteria pengujian menyebutkan apabila nilai 

signifikansi $\leq$ level of significance (alpha=5\% atau 0,05) maka dapat dinyatakan bahwa terdapat pengaruh yang signifikan.

\section{Uji Anova}

Tabel 3. Hasil Pengujian ANOVA

\begin{tabular}{cccc}
\hline $\begin{array}{c}\text { Variabel } \\
\text { Independen }\end{array}$ & Variabel Dependen & F Statistics & Sig. \\
\hline Online Review & $\begin{array}{c}\text { Attitude Toward } \\
\text { Destination } \\
\text { Intention To Visit } \\
\text { Destination } \\
\text { Online Review }\end{array}$ & 4032,301 & 0,000 \\
Virtual Reality & $\begin{array}{c}\text { Attude Toward } \\
\text { Destination } \\
\text { Intention To Visit } \\
\text { Destination }\end{array}$ & 51,379 & 0,000 \\
\hline
\end{tabular}

Sumber : hasil olah data SPSS

\section{Pengaruh Variabel Online Review (Positif dan Negatif) terhadap Attitude Toward Destination}

Berdasarkan hasil pada tabel 3 dapat diketahui bahwa nilai F statistik yang dihasilkan dari pengaruh online review (positif dan negatif) terhadap attitude toward destination adalah sebesar 4032,301 dengan nilai signifikansi sebesar 0,000. Nilai signifikansi tersebut lebih kecil dari significant alpha 5\% atau 0,05. Artinya bahwa terdapat pengaruh yang signifikan online review (positif dan negatif) terhadap attitude toward destination. Hasil ini diperkuat penelitian sebelumnya yaitu BrightLocal (2017) dan Chen \& Xie (2008), ketika membuat keputusan pembelian, $85 \%$ konsumen memercayai online review sebanyak rekomendasi pribadi.

Sehingga hipotesis 1 yang menyatakan terdapat pengaruh yang signifikan variabel online review (positif dan negatif) terhadap attitude toward destination dapat diterima. Rata-rata yang dihasilkan positive online review lebih besar dibandingkan negative online review yang artinya bahwa positive online review lebih mampu meningkatkan attitude toward destination. Hasil ini menyiratkan bahwa tinjauan campuran kurang efektif dibandingkan tinjauan valensi positif atau negatif dalam perubahan sikap. Selain itu, ketika konsumen mengevaluasi informasi yang masuk, mereka cenderung menilai dan menimbang informasi negatif lebih banyak daripada informasi positif (Ahluwalia, 2002; Baumeister et al., 2001).

Dibandingkan dengan tinjauan valensi positif atau negatif, tinjauan campuran mungkin memiliki pengaruh yang dilemahkan pada perubahan sikap konsumen karena ambiguitas tinjauan valensi. Selain itu, menurut efek negatif dari asimetri informasi, ulasan negatif akan memiliki efek yang lebih kuat pada perubahan sikap daripada ulasan positif (S. H. Lee \& Ro, 2016). Terkait dengan destinasi wisata, online review suatu destinasi wisata akan menentukan 
sikap wisatawan atas destinasi tersebut, oleh karena online review dapat memengaruhi attitude toward destination.

\section{Pengaruh Variabel Online Review (Positif dan Negatif) terhadap Intention to Visit Destination}

Berdasarkan hasil pada tabel 3 dapat diketahui bahwa nilai F statistik yang dihasilkan dari pengaruh online review (positif dan negatif) terhadap intention to visit destination adalah sebesar 3859,363 dengan nilai signifikansi sebesar 0,000. Nilai signifikansi tersebut lebih kecil dari significant alpha 5\% atau 0,05. Artinya bahwa terdapat pengaruh yang signifikan online review (positif dan negatif) terhadap intention to visit destination. Hasil ini diperkuat penelitian sebelumnya, Chevalier \& Mayzlin (2006) dan Zhu \& Zhang (2010) bahwa ulasan online menunjukkan dampak kuat pada perilaku pembelian konsumen.

Sehingga hipotesis 2 yang menyatakan terdapat pengaruh yang signifikan variabel online review (positif dan negatif) terhadap intention to visit destination dapat diterima. Rata-rata yang dihasilkan positive online review lebih besar dibandingkan negative online review yang artinya bahwa positive online review lebih mampu meningkatkan intention to visit destination. Hasil ini diperkuat penelitian pada perhotelan sebelumnya bahwa penilaian dan ulasan konsumen secara positif berhubungan dengan sikap terhadap hotel dan niat pemesanan (Sparks \& Browning, 2011; Tsao et al., 2015; Vermeulen \& Seegers, 2009). Hasil penelitian ini juga memengaruhi penjualan kamar hotel (Öğüt \& Onur Taş, 2012; Ye et al., 2009), dan niat kunjungan restoran (Zhang et al., 2010).

Niat pembelian adalah janji tersirat pada diri sendiri untuk membeli produk lagi setiap kali seseorang melakukan perjalanan berikutnya ke pasar (Tariq et al., 2013). Mengetahui niat pembelian untuk suatu merek adalah sangat penting karena menggambarkan kesan pelanggan. penyimpanan. Sikap merek, citra merek, kualitas, pengetahuan tentang merek, atribut, dan loyalitas merek adalah beberapa dimensi merek yang menjadi dasar kecenderungan pembelian (Tariq et al., 2013). Fungsi-fungsi ini memiliki pengaruh kuat pada purchase intention pelanggan. Demikian halnya, adanya online review mengenai suatu destinasi wisata akan menentukan niat wisatawan mengunjungi destinasi tersebut, oleh karena itu online review dapat memengaruhi intention to visit destination.

\section{Pengaruh Pengaplikasian Virtual Reality (Pengaplikasian VR dan Tidak Pengaplikasian VR) terhadap Attitude Toward Destination}

Berdasarkan hasil pada tabel 3 dapat diketahui bahwa nilai F statistik yang dihasilkan dari pengaruh pengaplikasian virtual reality (pengaplikasian VR dan tidak pengaplikasian VR) 
terhadap attitude toward destination adalah sebesar 51,379 dengan nilai signifikansi sebesar 0,000. Nilai signifikansi tersebut lebih kecil dari significant alpha 5\% atau 0,05. Artinya bahwa terdapat pengaruh yang signifikan pengaplikasian virtual reality (pengaplikasian VR dan tidak pengaplikasian VR) terhadap attitude toward destination. Hasil ini diperkuat penelitian sebelumnya, Y. C. Huang et al (2016) dan Stanley (2017) bahwa dunia VR telah memberikan peluang bagi pemasar destinasi untuk terhubung dengan calon pengunjung dengan memberikan pengalaman yang memungkinkan calon wisatawan untuk mencari destinasi pariwisata, dari kenyamanan rumah mereka sebelum mengambil keputusan untuk berkunjung.

Sehingga hipotesis 3 yang menyatakan terdapat pengaruh yang signifikan variabel pengaplikasian virtual reality (pengaplikasian VR dan tidak pengaplikasian VR) terhadap attitude toward destination dapat diterima. Rata-rata yang dihasilkan pengaplikasian VR lebih besar dibandingkan tidak pengaplikasian VR yang artinya bahwa pengaplikasian VR lebih mampu meningkatkan attitude toward destination. Hasi ini diperkuat penelitian sebelumnya, T. Kim \& Biocca (2006) dan Suh \& Lee (2005) menunjukkan bahwa rasa kehadiran di lingkungan VR memiliki konsekuensi positif pada perilaku pengguna. Memang, proposisi dan temuan utama dalam penelitian VR menunjukkan bahwa peningkatan rasa realitas dengan VR menghasilkan efek positif pada sikap, keyakinan, dan niat.

Klein (2003) mengidentifikasi bahwa kehadiran (tele) secara positif memengaruhi sikap konsumen terhadap produk yang diiklankan di lingkungan yang dimediasi komputer. Dalam konteks pariwisata, Hyun \& O'Keefe (2012) menemukan bahwa kehadiran (tele) melalui informasi yang dimediasi web secara langsung mengarah pada citra destinasi virtual yang positif. Oleh karena itu, dapat disarankan bahwa rasa kehadiran yang lebih tinggi di lingkungan VR akan menghasilkan sikap positif terhadap destinasi pariwisata. Sejalan virtual reality diterapkan pada destinasi wisata, oleh karena itu virtual reality dapat memengaruhi attitude toward destination.

\section{Pengaruh Pengaplikasian Virtual Reality (Pengaplikasian VR dan Tidak Pengaplikasian VR) terhadap Intention to Visit Destination}

Berdasarkan hasil pada tabel 3 dapat diketahui bahwa nilai F statistik yang dihasilkan dari pengaruh pengaplikasian virtual reality (pengaplikasian VR dan tidak pengaplikasian VR) terhadap intention to visit destination adalah sebesar 29,244 dengan nilai signifikansi sebesar 0,000. Nilai signifikansi tersebut lebih kecil dari significant alpha 5\% atau 0,05. Artinya bahwa terdapat pengaruh yang signifikan pengaplikasian virtual reality (pengaplikasian VR dan tidak pengaplikasian VR) terhadap intention to visit destination. Hasil ini diperkuat penelitian sebelumnya, Walsh \& Pawlowski (2002) dan Grewal et al. (2017) bahwa VR dapat diterapkan 
secara efektif untuk meningkatkan kinerja sistem informasi target dan berpotensi untuk merevolusi pengalaman berbelanja.

Sehingga hipotesis 4 yang menyatakan terdapat pengaruh yang signifikan variabel pengaplikasian virtual reality (pengaplikasian VR dan tidak pengaplikasian VR) terhadap intention to visit destination dapat diterima. Rata-rata yang dihasilkan pengaplikasian VR lebih besar dibandingkan tidak pengaplikasian VR yang artinya bahwa pengaplikasian VR lebih mampu meningkatkan intention to visit destination. Hasil ini diperkuat penelitian Meißner et al. (2017) dan van Herpen et al. (2016). Mengatakan bahwa realitas virtual mempertahankan sebagian besar modalitas perseptual termasuk khususnya persepsi 3D dan sensasi gerakan dan dengan demikian menghadirkan pengalaman yang lebih dekat dengan pengaturan target kehidupan nyata. Ini berarti ia dapat memberikan validitas eksternal yang lebih besar dari temuan ketika tujuannya adalah untuk menggeneralisasi temuan ke pengaturan tempat yang sebenarnya, sehingga dapat menambahakan niat berkunjung pada tempat wisata.

Wirth et al. (2007) berpendapat bahwa kemampuan spasial dapat berkontribusi pada pembentukan representasi spasial dari lingkungan yang dimediasi dalam pengalaman VR. Artinya, pengguna dengan citra visual spasial yang lebih tinggi mungkin akan lebih mudah membayangkan lingkungan VR dan mengisi informasi spasial yang hilang dari memori mereka.

\section{Uji Regresi}

Tabel 4. Hasil Analisis Regresi

\begin{tabular}{lccc}
\hline \multicolumn{1}{c}{ Variabel } & Koefisien & t & Sig. \\
\hline Constant &,- 020 &,- 615 & 0,539 \\
Attitude Toward Destination & 1,014 & 108,020 & 0,000 \\
\hline
\end{tabular}

Analisis regresi dimaksudkan untuk mengetahui apakah terdapat pengaruh yang signifikan attitude toward destination terhadap intention to visit destination. Kriteria pengujian menyatakan bahwa apabila nilai probabilitas < level of significant (alpha=5\% atau 0,05 ) maka dinyatakan adanya pengaruh variabel independen terhadap variabel dependen secara parsial.

\section{Pengaruh Variabel Attitude Toward Destination terhadap Intention to Visit Destination}

Berdasarkan hasil pada tabel 4.9 dapat diketahui bahwa nilai statistik uji t sebesar 108,020 dengan signifikansi yang dihasilkan sebesar 0,000. Nilai signifikansi tersebut lebih kecil dari significant alpha 5\% atau 0,05. Artinya bahwa terdapat pengaruh yang signifikan attitude toward destination terhadap intention to visit destination. Hasil ini diperkuat penelitian sebelumnya, Um \& Crompton (1990) dan Tsung Hung Lee (2009) menemukan bahwa sikap berpengaruh dalam menentukan apakah tujuan potensial dipilih sebagai bagian dari set yang 

dibangkitkan dan dalam memilih tujuan akhir dan juga menemukan bahwa sikap wisatawan memengaruhi perilaku wisatawan di masa depan.

Sehingga hipotesis 5 yang menyatakan terdapat pengaruh yang signifikan variabel attitude toward destination terhadap intention to visit destination dapat diterima. Koefisien yang dihasilkan sebesar 1,014 (positif) yang artinya bahwa semakin baik attitude toward destination, maka cenderung meningkatkan intention to visit destination. Hasil ini diperkuat Hartini et al. (2020) bahwa sikap merefleksikan evaluasi yang mendukung atau tidak mendukung, positif atau negatif, baik atau buruk, suka atau tidak suka terhadap objek. Suatu sikap mendorong konsumen untuk berperilaku tertentu atau menjauhkan konsumen untuk tidak melakukan suatu tindakan tertentu.

Hoyer et al. (2013) mendeskripsikan sikap sebagai keseluruhan evaluasi yang mengungkapkan pribadi yang menguntungkan atau tidak menyenangkan mengenai suatu objek, masalah, orang atau tindakan. Hal inilah yang menjadi alasan dibalik sikap individu terhadap iklan, brand dan lain sebagainya. Sikap sering digunakan untuk menilai efektivitas iklan karena dipandang sebagai prediktor kuat dari niat dan perilaku.

\section{Koefisien Determinasi}

Tabel 5. Hasil Koefisien Determinasi

\begin{tabular}{cccc}
\hline Model & $\mathrm{R}$ & R Square & $\begin{array}{c}\text { Adjusted R } \\
\text { Square }\end{array}$ \\
\hline 1 & 0,993 & 0,987 & 0,987 \\
\hline
\end{tabular}

Koefisien determinasi dalam penelitian ini digunakan untuk mengetahui kontribusi pengaruh variabel attitude toward destination terhadap intention to visit destination. Nilai koefisien determinasi dilambangkan dengan $\mathrm{R}^{2}$. Nilai $\mathrm{R}^{2}$ yang mendekati 1 menandakan kontribusi yang kuat. Berdasarkan tabel di atas diketahui bahwa nilai koefisien determinasi sebesar 0,987. Artinya bahwa kontribusi pengaruh variabel attitude toward destination terhadap intention to visit destination sebesar 98,7\%. Sedangkan sisanya sebesar 1,3\% dipengaruhi oleh variabel diluar penelitian ini.

\section{CONCLUSION AND SUGGESTION}

Online review (positif dan negatif) terdapat pengaruh yang signifikan terhadap attitude toward destination. Rata-rata yang dihasilkan positive online review lebih besar dibandingkan negative online review yang artinya bahwa positive online review lebih mampu meningkatkan attitude toward destination. Online review (positif dan negatif) juga berpengaruh yang signifikan terhadap intention to visit destination dapat diterima. Rata-rata yang dihasilkan 
positive online review lebih besar dibandingkan negative online review yang artinya bahwa positive online review lebih mampu meningkatkan intention to visit destination. Sedangkan pengaplikasian virtual reality (pengaplikasian VR dan tidak pengaplikasian VR) terdapat pengaruh yang signifikan terhadap attitude toward destination. Rata-rata yang dihasilkan pengaplikasian VR lebih besar dibandingkan tidak pengaplikasian VR yang artinya bahwa pengaplikasian VR lebih mampu meningkatkan attitude toward destination. Pengaplikasian virtual reality (pengaplikasian VR dan tidak pengaplikasian VR) juga berpengaruh yang signifikan terhadap intention to visit destination. Rata-rata yang dihasilkan pengaplikasian VR lebih besar dibandingkan tidak pengaplikasian VR yang artinya bahwa pengaplikasian VR lebih mampu meningkatkan intention to visit destination. Attitude toward destination terdapat pengaruh yang signifikan terhadap intention to visit destination. Bahwa semakin baik attitude toward destination, maka cenderung meningkatkan intention to visit destination. Dalam penelitian ini terlihat bahwa sikap terhadap destinasi wisata yang dirasakan konsumen dapat memperkuat atau memperlemah niat untuk mengunjungi destinasi wisata.

\section{BIBLIOGRAPHY}

Accenture. (2018). Redefine Your Company Based on the Company You Keep: Intelligent Enterprise Unleashed. Accenture.

Advertorial. (2019). Jakarta Aquarium Sajikan Sensasi Dalam Laut di Tengah Kota. Mediaindonesia.Com. sumber: https://mediaindonesia.com/advertorial/261329/jakartaaquarium-sajikan-sensasi-dalam-laut-di-tengah-kota

Ahluwalia, R. (2002). How Prevalent Is the Negativity Effect in Consumer Environments? Journal of Consumer Research. https://doi.org/10.1086/341576

Ajzen, I. (1991). The theory of planned behavior. Organizational Behavior and Human Decision Processes. https://doi.org/10.1016/0749-5978(91)90020-T

Ajzen, I. (2001). Nature and operation of attitudes. Annual Review of Psychology. https://doi.org/10.1146/annurev.psych.52.1.27

Ajzen, I. (2005). Attitudes, Personality and Behavior (Second Edition). In Open University Press. https://doi.org/10.1037/e418632008-001

Ajzen, I., \& Fishbein, M. (2000). Attitudes and the Attitude-Behavior Relation: Reasoned and Automatic Processes. European Review of Social Psychology. https://doi.org/10.1080/14792779943000116

Algharabat, R., \& Dennis, C. (2010). Using authentic 3D product visualisation for an electrical online retailer. Journal of Customer Behaviour, 9(2), 97-115. https://doi.org/10.1362/147539210x511326

Ali, F. (2016). Hotel website quality, perceived flow, customer satisfaction and purchase intention. Journal of Hospitality and Tourism Technology. https://doi.org/10.1108/JHTT02-2016-0010 
Stefanus Alvin Hartono, S.Kom \& Dr. Sri Hatini SE., M.Si/ Ekonika vol 6 (2) 2021

Amalia, F. (2011). Analisis Pengaruh Faktor Budaya, Sosial, Pribadi Dan Psikologis Terhadap Keputusan Pembelian Minuman Penambah Tenaga Cair Merek M - 150 Di Semarang. Universitas Diponegoro Semarang.

Anderson, M. (2013). 2013 Study: 79\% of consumers trust online reviews as much as personal recommendations. Retrieved from http://searchengineland.com/2013-study-79-ofconsumers-trust-online-reviews-as-much-as-personal-recommendations-164565. https://searchengineland.com/2013-study-79-of-consumers-trust-online-reviews-asmuch-as-personal-recommendations- 164565

Anderson, N. H. (1971). Integration theory and attitude change. Psychological Review. https://doi.org/10.1037/h0030834

Arndt, J. (1967). Role of Product-Related Conversations in the Diffusion of a New Product. Journal of Marketing Research. https://doi.org/10.2307/3149462

Baumeister, R. F., Bratslavsky, E., Finkenauer, C., \& Vohs, K. D. (2001). Bad is stronger than good. Review of General Psychology. https://doi.org/10.1037//1089-2680.5.4.323

Bei, L. T., Chen, E. Y. I., \& Widdows, R. (2004). Consumers' online information search behavior and the phenomenon of search vs. experience products. Journal of Family and Economic Issues. https://doi.org/10.1007/s10834-004-5490-0

Berger, J., Sorensen, A. T., \& Rasmussen, S. J. (2010). Positive effects of negative publicity: When negative reviews increase sales. Marketing Science. https://doi.org/10.1287/mksc.1090.0557

Bickart, B., \& Schindler, R. M. (2001). Internet forums as influential sources of consumer information. Journal of Interactive Marketing. https://doi.org/10.1002/dir.1014

Bogicevic, V., Seo, S., Kandampully, J. A., Liu, S. Q., \& Rudd, N. A. (2019). Virtual reality presence as a preamble of tourism experience: The role of mental imagery. Tourism Management. https://doi.org/10.1016/j.tourman.2019.02.009

Bohil, C. J., Alicea, B., \& Biocca, F. A. (2011). Virtual reality in neuroscience research and therapy. In Nature Reviews Neuroscience. https://doi.org/10.1038/nrn3122

Bonabeau, E. (2004). The perils of the imitation age. In Harvard Business Review.

Braun-LaTour, K. A., Grinley, M. J., \& Loftus, E. F. (2006). Tourist memory distortion. Journal of Travel Research. https://doi.org/10.1177/0047287506286721

Braun, K. A. (1999). Postexperience advertising effects on consumer memory. Journal of Consumer Research. https://doi.org/10.1086/209542

Breckler, S. J. (1984). Empirical validation of affect, behavior, and cognition as distinct components of attitude. Journal of Personality and Social Psychology. https://doi.org/10.1037/0022-3514.47.6.1191

BrightLocal. (2017). Local consumer review survey. BrightLocal. https://www.brightlocal.com/research/local-consumer-review-survey/

Brown, G. (2006). Mapping Landscape Values and. Tourism, 113(November 2012), 101-113. https://doi.org/10.1002/jtr

Brown, J., Broderick, A. J., \& Lee, N. (2007). Word of mouth communication within online communities: Conceptualizing the online social network. Journal of Interactive Marketing. https://doi.org/10.1002/dir.20082 
Buttle, F. A. (1998). Word of mouth: Understanding and managing referral marketing. Journal of Strategic Marketing. https://doi.org/10.1080/096525498346658

Chang, H. H., Rizal, H., \& Amin, H. (2013). The determinants of consumer behavior towards email advertisement. Internet Research. https://doi.org/10.1108/10662241311331754

Chang, L. (1998). Factors Influencing Changsha Teenagers'Purchase Intention Towards Celebrity-Endorsed Apparels. Assumption University, Master of Business Administration, Graduate School of Business.

Chen, Y., \& Xie, J. (2008). Online consumer review: Word-of-mouth as a new element of marketing communication mix. Management Science. https://doi.org/10.1287/mnsc.1070.0810

Cheong, R. (1995). The virtual threat to travel and tourism. Tourism Management. https://doi.org/10.1016/0261-5177(95)00049-T

Cheung, M., Luo, C., Sia, C., \& Chen, H. (2009). Credibility of electronic word-of-mouth: Informational and normative determinants of on-line consumer recommendations. International Journal of Electronic Commerce. https://doi.org/10.2753/JEC10864415130402

Chevalier, J. A., \& Mayzlin, D. (2006). The effect of word of mouth on sales: Online book reviews. In Journal of Marketing Research. https://doi.org/10.1509/jmkr.43.3.345

Chiou, J. S., \& Cheng, C. (2003). Should a company have message boards on its web sites? Journal of Interactive Marketing. https://doi.org/10.1002/dir.10059

Cialdini, R. B., \& Goldstein, N. J. (2004). Social influence: Compliance and conformity. Annual Review of Psychology. https://doi.org/10.1146/annurev.psych.55.090902.142015

Clemons, E. K., Gao, G., \& Hitt, L. M. (2006). When online reviews meet hyperdifferentiation: A study of the craft beer industry. In Journal of Management Information Systems. https://doi.org/10.2753/MIS0742-1222230207

Coates, D., Curwin, J., \& Slater, R. (1992). Quantitative Methods for Business Decisions (3rd Edition). The Journal of the Operational Research Society, 43(4), 367. https://doi.org/10.2307/2583163

Coates, G. (1992). "Program from Invisible Site-a virtual sho, a multimedia performance work presented by George Coates Performance Works." "Program from Invisible Site-a Virtual Sho, a Multimedia Performance Work Presented by George Coates Performance Works.” https://doi.org/10.1017/CBO9781107415324.004

Cowley, E. (2007). How enjoyable was it? Remembering an affective reaction to a previous consumption experience. Journal of Consumer Research. https://doi.org/10.1086/520072

Cui, G., Lui, H. K., \& Guo, X. (2012). The effect of online consumer reviews on new product sales. International Journal of Electronic Commerce. https://doi.org/10.2753/JEC10864415170102

Doh, S. J., \& Hwang, J. S. (2009). How consumers evaluate eWOM (electronic word-of-mouth) messages. Cyberpsychology and Behavior. https://doi.org/10.1089/cpb.2008.0109

Duan, W., Gu, B., \& Whinston, A. B. (2008). Do online reviews matter? - An empirical investigation of panel data. Decision Support Systems. https://doi.org/10.1016/j.dss.2008.04.001

Duhachek, A., Zhang, S., \& Krishnan, S. (2007). Anticipated group interaction: Coping with 

valence asymmetries in attitude shift. Journal of Consumer Research. https://doi.org/10.1086/518543

Eagly, A. H., \& Chaiken, S. (1993). The Psychology of Attitudes: Book Review. In Fort Worth, TX: Harcourt Brace Jovanovich. https://doi.org/10.1177/1748895810383803

East, R., Hammond, K., \& Lomax, W. (2008). Measuring the impact of positive and negative word of mouth on brand purchase probability. International Journal of Research in Marketing. https://doi.org/10.1016/j.ijresmar.2008.04.001

East, R., Hammond, K., \& Wright, M. (2007). The relative incidence of positive and negative word of mouth: A multi-category study. International Journal of Research in Marketing. https://doi.org/10.1016/j.ijresmar.2006.12.004

Fishbein, M., \& Ajzen, I. (1975). Chapter 1. Belief, Attitude, Intention, and Behavior: An Introduction to Theory and Research. In Reading, MA: Addison-Wesley. https://doi.org/10.1017/CBO9781107415324.004

Fiske, S. T. (1980). Attention and weight in person perception: The impact of negative and extreme behavior. Journal of Personality and Social Psychology. https://doi.org/10.1037/0022-3514.38.6.889

Franke, G. R., Huhmann, B. A., \& Mothersbaugh, D. L. (2004). Information Content and Consumer Readership of Print Ads: A Comparison of Search and Experience Products. In Journal of the Academy of Marketing Science. https://doi.org/10.1177/0092070303257856

Gershoff, A. D., Mukherjee, A., \& Mukhopadhyay, A. (2003). Consumer acceptance of online agent advice: Extremity and positivity effects. Journal of Consumer Psychology. https://doi.org/10.1207/s15327663jcp13-1\&2_14

Ghozali, I. (2009). Aplikasi Multivariate dengan Program SPSS edisi III. Semarang: Badan Penerbit UNDIP. https://doi.org/10.1016/j.00oo.2017.11.003

Gibson, C. (2009). Geographies of tourism: Critical research on capitalism and local livelihoods. Progress in Human Geography. https://doi.org/10.1177/0309132508099797

Goldsmith, R. E., \& Horowitz, D. (2006). Measuring Motivations for Online Opinion Seeking. Journal of Interactive Advertising. https://doi.org/10.1080/15252019.2006.10722114

Grewal, D., Roggeveen, A. L., \& Nordfält, J. (2017). The Future of Retailing. Journal of Retailing. https://doi.org/10.1016/j.jretai.2016.12.008

Guttentag, D. A. (2010). Virtual reality: Applications and implications for tourism. Tourism Management. https://doi.org/10.1016/j.tourman.2009.07.003

Harris, J., \& Gupta, P. (2008). "You should buy this one!" The influence of online recommendations on product attitudes and choice confidence. International Journal of Electronic Marketing and Retailing. https://doi.org/10.1504/IJEMR.2008.019816

Hartini, S., Anglelyn, C., \& Sukaris, S. (2020). Virtual reality: aplikasi teknologi untuk peningkatan kunjungan wisatawan. Journal of Business and Banking, 9(2), 215. https://doi.org/10.14414/jbb.v9i2.2014

Hartono, J. (2015). Konsep dan Aplikasi Structural Equation Modeling (SEM) Berbasis Varian dalam Penelitian Bisnis. Public Administration Review.

Hausman, A. V., \& Siekpe, J. S. (2009). The effect of web interface features on consumer online purchase intentions. Journal of Business Research. 
https://doi.org/10.1016/j.jbusres.2008.01.018

Hennig-Thurau, T., Gwinner, K. P., Walsh, G., \& Gremler, D. D. (2004). Electronic word-ofmouth via consumer-opinion platforms: What motivates consumers to articulate themselves on the Internet? Journal of Interactive Marketing. https://doi.org/10.1002/dir.10073

Herr, P. M., Kardes, F. R., \& Kim, J. (1991). Effects of Word-of-Mouth and Product-Attribute Information on Persuasion: An Accessibility-Diagnosticity Perspective. Journal of Consumer Research. https://doi.org/10.1086/208570

Hoch, S. J., \& Deighton, J. (1989). Managing What Consumers Learn from Experience. Journal of Marketing. https://doi.org/10.2307/1251410

Hoch, S. J., \& Ha, Y.-W. (1986). Consumer Learning: Advertising and the Ambiguity of Product Experience. Journal of Consumer Research. https://doi.org/10.1086/209062

Holbrook, M. B., \& Moore, W. L. (1981). Feature Interactions in Consumer Judgments of Verbal versus Pictorial Presentations. Journal of Consumer Research, 8(1), 103. https://doi.org/10.1086/208846

Hosein, N. Z. (2012). Measuring the Purchase Intention of Visitors to the Auto Show. Journal of Management \& Marketing Research.

Hoyer, MacInnis, Pieters, MacInnis, D.J. and Pieters, R. (2013). Consumer Behavior International Edition. In Introduction to mediation, moderation and conditional process analysis, second edition: A regression-based approach. https://doi.org/978-1-60918-2304

Hsu, C. L., \& Lin, J. C. C. (2008). Acceptance of blog usage: The roles of technology acceptance, social influence and knowledge sharing motivation. Information and Management. https://doi.org/10.1016/j.im.2007.11.001

Hu, Y., \& Kim, H. J. (2018). Positive and negative eWOM motivations and hotel customers' eWOM behavior: Does personality matter? International Journal of Hospitality Management, 75(March), 27-37. https://doi.org/10.1016/j.ijhm.2018.03.004

Huang, J. H., \& Chen, Y. F. (2006). Herding in online product choice. Psychology and Marketing. https://doi.org/10.1002/mar.20119

Huang, Y. C., Backman, K. F., Backman, S. J., \& Chang, L. L. (2016). Exploring the Implications of Virtual Reality Technology in Tourism Marketing: An Integrated Research Framework. International Journal of Tourism Research. https://doi.org/10.1002/jtr.2038

Huang, Y. C., Backman, S. J., Backman, K. F., \& Moore, D. W. (2013). Exploring user acceptance of 3D virtual worlds in travel and tourism marketing. Tourism Management. https://doi.org/10.1016/j.tourman.2012.09.009

Huh, Y. E., Vosgerau, J., \& Morewedge, C. K. (2014). Social defaults: Observed choices become choice defaults. Journal of Consumer Research. https://doi.org/10.1086/677315

Hwang, J., Park, S., \& Woo, M. (2018). Understanding user experiences of online travel review websites for hotel booking behaviours: an investigation of a dual motivation theory. Asia Pacific Journal of Tourism Research. https://doi.org/10.1080/10941665.2018.1444648

Hyun, M. Y., \& O'Keefe, R. M. (2012). Virtual destination image: Testing a telepresence model. Journal of Business Research. https://doi.org/10.1016/j.jbusres.2011.07.011 
Iachini, T., Maffei, L., Masullo, M., Senese, V. P., Rapuano, M., Pascale, A., Sorrentino, F., \& Ruggiero, G. (2019). The experience of virtual reality: are individual differences in mental imagery associated with sense of presence? Cognitive Processing. https://doi.org/10.1007/s10339-018-0897-y

Irianto, A. (2004). Statistik Konsep Dasar, Aplikasi dan Pengembangannya. In Standard Methods for the Examination of Water and Wastewater. https://doi.org/10.1590/S151618462008000300012

John, D. R. (1999). Consumer socialization of children: A retrospective look at twenty-five years of research. Journal of Consumer Research. https://doi.org/10.1086/209559

Jung, T., Dieck, M. C. T., Moorhouse, N., \& Dieck, D. T. (2017). Tourists' experience of Virtual Reality applications. 2017 IEEE International Conference on Consumer Electronics, ICCE 2017. https://doi.org/10.1109/ICCE.2017.7889287

Jung, T., tom Dieck, M. C., Lee, H., \& Chung, N. (2016). Effects of Virtual Reality and Augmented Reality on Visitor Experiences in Museum. In Information and Communication Technologies in Tourism 2016. https://doi.org/10.1007/978-3-31928231-2_45

Kahneman, D., \& Tversky, A. (1979). Kahneman, D., \& Tversky, A. (1979). Prospect theory: An analysis of decision under risk. Econometrika, 47, 263-291. Econometrica. https://doi.org/10.2307/1914185

Kamakura, W. A., Basuroy, S., \& Boatwright, P. (2006). Is silence golden? An inquiry into the meaning of silence in professional product evaluations. Quantitative Marketing and Economics. https://doi.org/10.1007/s11129-006-3181-x

Kang, H. J., Shin, J. hye, \& Ponto, K. (2020). How 3D Virtual Reality Stores Can Shape Consumer Purchase Decisions: The Roles of Informativeness and Playfulness. Journal of Interactive Marketing, 49, 70-85. https://doi.org/10.1016/j.intmar.2019.07.002

Karmarkar, U. R., \& Tormala, Z. L. (2010). Believe me, I have no idea what i'm talking about: The effects of source certainty on consumer involvement and persuasion. Journal of Consumer Research. https://doi.org/10.1086/648381

Kim, E. E. K., Mattila, A. S., \& Baloglu, S. (2011). Effects of gender and expertise on consumers' motivation to read online hotel reviews. Cornell Hospitality Quarterly. https://doi.org/10.1177/1938965510394357

Kim, T., \& Biocca, F. (2006). Telepresence via Television: Two Dimensions of Telepresence May Have Different Connections to Memory and Persuasion.[1]. Journal of ComputerMediated Communication. https://doi.org/10.1111/j.1083-6101.1997.tb00073.x

Klein, L. R. (2003). Creating virtual product experiences: The role of telepresence. Journal of Interactive Marketing. https://doi.org/10.1002/dir.10046

Kotler, P., \& Keller, K. L. (2016). Marketing Management 15/e. In Prentice Hall. https://doi.org/10.1080/08911760903022556

Kraus, S. J. (1995). Attitudes and the Prediction of Behavior: A Meta-Analysis of the Empirical Literature. Personality and Social Psychology Bulletin. https://doi.org/10.1177/0146167295211007

Lee, E. J., \& Shin, S. Y. (2014). When do consumers buy online product reviews? Effects of review quality, product type, and reviewer's photo. Computers in Human Behavior. https://doi.org/10.1016/j.chb.2013.10.050 
Lee, J., Park, D. H., \& Han, I. (2008). The effect of negative online consumer reviews on product attitude: An information processing view. Electronic Commerce Research and Applications. https://doi.org/10.1016/j.elerap.2007.05.004

Lee, J., Park, D. H., \& Han, I. (2011). The different effects of online consumer reviews on consumers' purchase intentions depending on trust in online shopping malls: An advertising perspective. Internet Research. https://doi.org/10.1108/10662241111123766

Lee, K. C., \& Chung, N. (2008). Empirical analysis of consumer reaction to the virtual reality shopping mall. Computers in Human Behavior, 24(1), 88-104. https://doi.org/10.1016/j.chb.2007.01.018

Lee, M., \& Youn, S. (2009). Electronic word of mouth (eWOM). International Journal of Advertising. https://doi.org/10.2501/s0265048709200709

Lee, S. H., \& Ro, H. (2016). The impact of online reviews on attitude changes: The differential effects of review attributes and consumer knowledge. International Journal of Hospitality Management. https://doi.org/10.1016/j.ijhm.2016.04.004

Lee, T. H. (2007). An ecotourism behavioural model of national forest recreation areas in Taiwan. International Forestry Review. https://doi.org/10.1505/ifor.9.3.771

Lee, Tsung Hung. (2009). A Structural model to examine how destination image, attitude, and motivation affect the future behavior of tourists. Leisure Sciences. https://doi.org/10.1080/01490400902837787

Leonardis, D., Frisoli, A., Barsotti, M., Carrozzino, M., \& Bergamasco, M. (2014). Multisensory feedback can enhance embodiment within an enriched virtual walking scenario. Presence: Teleoperators and Virtual Environments. https://doi.org/10.1162/PRES_a_00190

Lester, D. H., Forman, A. M., \& Loyd, D. (2006). Internet shopping and buying behavior of college students. In Services Marketing Quarterly. https://doi.org/10.1300/J396v27n02_08

Li, H., Daugherty, T., \& Biocca, F. (2001). Characteristics of virtual experience in electronic commerce: A protocol analysis. Journal of Interactive Marketing. https://doi.org/10.1002/dir.1013

Li, H., Daugherty, T., \& Biocca, F. (2002). Impact of 3-D advertising on product knowledge, brand attitude, and purchase intention: The mediating role of presence. Journal of Advertising, 31(3), 43-57. https://doi.org/10.1080/00913367.2002.10673675

Li, T., \& Chen, Y. (2019). Will virtual reality be a double-edged sword? Exploring the moderation effects of the expected enjoyment of a destination on travel intention. Journal of Destination Marketing and Management, 12(101), 15-26. https://doi.org/10.1016/j.jdmm.2019.02.003

Lin, C., Wu, Y.-S., \& Chen, J.-C. V. (2013). Electronic Word-of-Mouth: The Moderating Roles of Product Involvement and Brand Image. Proceedings of 2013 International Conference on Technology Innovation and Industrial Management.

Liu, Y. (2006). Word of mouth for movies: Its dynamics and impact on box office revenue. In Journal of Marketing. https://doi.org/10.1509/jmkg.70.3.74

Loftus, E. F. (2004). Memory and its distortions. In The G. Stanley Hall lecture series, Vol. 2. https://doi.org/10.1037/10087-003 
Lombard, M., \& Ditton, T. (1997). At the Heart of It All: The Concept of Presence - Lombard - 2006 - Journal of Computer-Mediated Communication - Wiley Online Library. In Journal of Computer-Mediated Communication. https://doi.org/10.1111/j.10836101.1997.tb00072.xView/save

López, M., \& Sicilia, M. (2014). eWOM as Source of Influence: The Impact of Participation in eWOM and Perceived Source Trustworthiness on Decision Making. Journal of Interactive Advertising. https://doi.org/10.1080/15252019.2014.944288

Lu, L. C., Chang, W. P., \& Chang, H. H. (2014). Consumer attitudes toward blogger's sponsored recommendations and purchase intention: The effect of sponsorship type, product type, and brand awareness. Computers in Human Behavior. https://doi.org/10.1016/j.chb.2014.02.007

Luca, M. (2012). Reviews, Reputation, and Revenue: The Case of Yelp.Com. SSRN Electronic Journal. https://doi.org/10.2139/ssrn.1928601

Lutz, R. J. (1975a). Changing Brand Attitudes Through Modification of Cognitive Structure. Journal of Consumer Research. https://doi.org/10.1086/208607

Lutz, R. J. (1975b). The Role of Attitude Theory in Marketing. In Perspectives in Consumer Behavior.

M. Iqbal, H. H. (2002). Pokok-pokok Materi Statistik I ( Statistik Deskriptif). In Statistik deskriptif. https://doi.org/10.1007/b137665

MacLin, M. Kimberly, and Solso, R. L. (2008). Experimental psychology: a case approach. Pearson/Allyn \& Bacon.

Maheswaran, D., \& Meyers-Levy, J. (1990). The Influence of Message Framing and Issue Involvement. Journal of Marketing Research. https://doi.org/10.2307/3172593

Malhotra, N. K. (2009). Riset Pemasaran, Edisi keempat, Jilid 1. Jakarta: PT Indeks. https://doi.org/10.1163/_q3_SIM_00374

Malhotra, N. K. (2010). Questionnaire and Form Design. In Marketing Research: An Applied Orientation.

Marasco, A., Buonincontri, P., van Niekerk, M., Orlowski, M., \& Okumus, F. (2018). Exploring the role of next-generation virtual technologies in destination marketing. Journal of Destination Marketing and Management. https://doi.org/10.1016/j.jdmm.2017.12.002

McDaniel, C. J., \& Gates, R. (2011). Marketing Research Essentials. Marketing Research Essentials, 7th Edition.

Meißner, W., Komann, M., Erlenwein, J., Stamer, U., \& Scherag, A. (2017). The Quality of Postoperative Pain Therapy in German Hospitals. Deutsches Aerzteblatt Online. https://doi.org/10.3238/arztebl.2017.0161

Moe, W. W., \& Fader, P. S. (2004). Capturing evolving visit behavior in clickstream data. Journal of Interactive Marketing. https://doi.org/10.1002/dir.10074

Moe, W. W., \& Schweidel, D. A. (2012). Online product opinions: Incidence, evaluation, and evolution. Marketing Science. https://doi.org/10.1287/mksc.1110.0662

Moe, W. W., Trusov, M., \& Smith, R. H. (2011). The value of social dynamics in online product ratings forums. Journal of Marketing Research. https://doi.org/10.1509/jmkr.48.3.444

Naylor, R. W., Lamberton, C. P., \& West, P. M. (2012). Beyond the "like" button: The impact 
of mere virtual presence on brand evaluations and purchase intentions in social media settings. Journal of Marketing. https://doi.org/10.1509/jm.11.0105

Öğüt, H., \& Onur Taş, B. K. (2012). The influence of internet customer reviews on the online sales and prices in hotel industry. Service Industries Journal. https://doi.org/10.1080/02642069.2010.529436

Paivio, A. (1990). Mental representations: A dual coding approach. Oxford University Press. https://books.google.co.id/books?hl=en\&lr=\&id=hLGmKkh_4K8C\&oi=fnd\&pg=PA3\& ots=B4H19Dinqn\&sig=I2yJRJWpAbS7Otpwc16OlWBREfw\&redir_esc $=\mathrm{y} \# \mathrm{v}=$ onepage $\& \mathrm{q} \& \mathrm{f}=$ false

Pan, L. Y., \& Chiou, J. S. (2011). How Much Can You Trust Online Information? Cues for Perceived Trustworthiness of Consumer-generated Online Information. Journal of Interactive Marketing. https://doi.org/10.1016/j.intmar.2011.01.002

Park, D. H., Lee, J., \& Han, I. (2007). The effect of on-line consumer reviews on consumer purchasing intention: The moderating role of involvement. In International Journal of Electronic Commerce. https://doi.org/10.2753/JEC1086-4415110405

Pennington, J., \& Schlenker, B. R. (1999). Accountability for consequential decisions: Justifying ethical judgments to audiences. Personality and Social Psychology Bulletin. https://doi.org/10.1177/01461672992512001

Perry Hobson, J. S., \& Williams, A. P. (1995). Virtual reality: A new horizon for the tourism industry. Journal of Vacation Marketing. https://doi.org/10.1177/135676679500100202

Petty, Richard, Thomas M. Ostrom, and Timothy C. Brock, eds. (2014). Cognitive responses in persuasion. Psychology Press. https://scholar.google.com/scholar_lookup?title=Cognitive Persuasion\&author=Richard Petty\&publication_year=1981

Responses in

Petty, R. E. (2012). Attitude Change. Encyclopedia of Human Behavior: Second Edition, January 2010, 224-229. https://doi.org/10.1016/B978-0-12-375000-6.00040-9

Peukert, C., Pfeiffer, J., Meißner, M., Pfeiffer, T., \& Weinhardt, C. (2019). Shopping in Virtual Reality Stores: The Influence of Immersion on System Adoption. Journal of Management Information Systems. https://doi.org/10.1080/07421222.2019.1628889

Pieters, R., \& Wedel, M. (2004). Attention Capture and Transfer in Advertising: Brand, Pictorial, and Text-Size Effects. Journal of Marketing. https://doi.org/10.1509/jmkg.68.2.36.27794

Pola, F. I. T. S., \& Berbasis, J. (2004). Metode Penelitian Metode Penelitian. 22-34.

Pramesti, G. (2016). Statistika Lengkap secara Teori dan Aplikasi dengan SPSS 23. In Elex Media Komputindo.

Quinn, A., \& Schlenker, B. R. (2002). Can accountability produce independence? Goals as determinants of the impact of accountability on conformity. In Personality and Social Psychology Bulletin. https://doi.org/10.1177/0146167202287005

Racherla, P., \& Friske, W. (2012). Perceived "usefulness" of online consumer reviews: An exploratory investigation across three services categories. Electronic Commerce Research and Applications. https://doi.org/10.1016/j.elerap.2012.06.003

Raney, A. A., Arpan, L. M., PashuPati, K., \& Brill, D. A. (2003). At the movies, on the web: An investigation of the effects of entertaining and interactive web content on site and

Pengaruh Online Review dan Virtual Reality Terhadap Attitude Toward Destination dan Intention to Visit Destination

(C) 2021 Ekonika : Jurnal Ekonomi Universitas Kadiri. Semua hak cipta dilindungi undang-undang 

brand evaluations. Journal of Interactive Marketing. https://doi.org/10.1002/dir.10064

Ryan, R. M., \& Deci, E. L. (2000). Intrinsic and Extrinsic Motivations: Classic Definitions and New Directions. Contemporary Educational Psychology. https://doi.org/10.1006/ceps.1999.1020

Schiffman, L.G. and Kanuk, L. L. (1994). Consumer behavior ((5th ed.). Englewood Cliffs, NJ : $\quad$ Prentice Hall, (C) 1994. https://www.scirp.org/(S(351jmbntvnsjt1aadkposzje))/reference/ReferencesPapers.aspx ?ReferenceID $=1471953$

Schlosser, A. E. (2005). Posting versus lurking: Communicating in a multiple audience context. In Journal of Consumer Research. https://doi.org/10.1086/432235

Schuemie, M. J., Van der Straaten, P., Krijn, M., \& Van der Mast, C. A. P. G. (2001). Research on presence in virtual reality: A survey. In Cyberpsychology and Behavior. https://doi.org/10.1089/109493101300117884

Sekaran, U. (2011). Metodologi Penelitian untuk Bisnis. Jakarta: Salemba Empat. Annals of Tourism Research. https://doi.org/10.1016/j.annals.2015.12.019

Sen, S., \& Lerman, D. (2007). Why are you telling me this? An examination into negative consumer reviews on the web. Journal of Interactive Marketing. https://doi.org/10.1002/dir.20090

Shi, X., \& Liao, Z. (2017). Online consumer review and group-buying participation: The mediating effects of consumer beliefs. Telematics and Informatics. https://doi.org/10.1016/j.tele.2016.12.001

Shukla, P. (2011). Impact of interpersonal influences, brand origin and brand image on luxury purchase intentions: Measuring interfunctional interactions and a cross-national comparison. Journal of World Business. https://doi.org/10.1016/j.jwb.2010.11.002

Sicilia, M., Ruiz, S., \& Reynolds, N. (2006). Attitude formation online: How the consumer's need for cognition affects the relationship between attitude towards the website and attitude towards the brand. In International Journal of Market Research. https://doi.org/10.1177/147078530604800204

Singh, J., \& Pandya, S. (1991). Exploring the Effects of Consumers' Dissatisfaction Level on Complaint Behaviours. European Journal of Marketing. https://doi.org/10.1108/eum0000000000621

Skowronski, J. J., \& Carlston, D. E. (1989). Negativity and Extremity Biases in Impression Formation: A Review of Explanations. In Psychological Bulletin. https://doi.org/10.1037/0033-2909.105.1.131

Slater, M. (1999). Article in Presence Teleoperators \& Virtual Environments . Researchgate.Net. https://doi.org/10.1162/105474699566477

Slater, M., \& Sanchez-Vives, M. V. (2016). Enhancing our lives with immersive virtual reality. In Frontiers Robotics AI. https://doi.org/10.3389/frobt.2016.00074

Slater, M., \& Usoh, M. (1993). Representations Systems, Perceptual Position, and Presence in Immersive Virtual Environments. Presence: Teleoperators and Virtual Environments, 2(3), 221-233. https://doi.org/10.1162/pres.1993.2.3.221

Slater, M., Usoh, M., \& Steed, A. (1994). Depth of Presence in Virtual Environments. Presence: Teleoperators and Virtual Environments. https://doi.org/10.1162/pres.1994.3.2.130 
Smith, R. E. (1993). Integrating Information from Advertising and Trial: Processes and Effects on Consumer Response to Product Information. Journal of Marketing Research. https://doi.org/10.2307/3172828

Sparks, B. A., \& Browning, V. (2011). The impact of online reviews on hotel booking intentions and perception of trust. Tourism Management. https://doi.org/10.1016/j.tourman.2010.12.011

Spears, N., \& Singh, S. N. (2004). Measuring attitude toward the brand and purchase intentions. Journal of Current Issues and Research in Advertising. https://doi.org/10.1080/10641734.2004.10505164

Sridhar, S., \& Srinivasan, R. (2012). Social influence effects in online product ratings. In Journal of Marketing. https://doi.org/10.1509/jm.10.0377

Stanley, A. (2017). Virtual reality experiences becoming big part of tourism campaigns. http://www.travelweek.ca/news/virtual-reality-experiences-becoming-big-part-tourismcampaigns/

Steenjacobsen, J. K. (2001). Nomadic tourism and fleeting place encounters: Exploring different aspects of sightseeing. Scandinavian Journal of Hospitality and Tourism, 1(2), 99-112. https://doi.org/10.1080/150222501317244029

Steuer, J. (1992). Defining Virtual Reality: Dimensions Determining Telepresence. Journal of Communication. https://doi.org/10.1111/j.1460-2466.1992.tb00812.x

Sugiyono. (2014). Metode dan Prosedur Penelitian. E-Journal.

Suh, K. S., \& Chang, S. (2006). User interfaces and consumer perceptions of online stores: The role of telepresence. Behaviour and Information Technology. https://doi.org/10.1080/01449290500330398

Suh, K. S., \& Lee, Y. E. (2005). The effects of virtual reality on consumer learning: An empirical investigation. MIS Quarterly: Management Information Systems, 29(4), 673697. https://doi.org/10.2307/25148705

Sun, X., Han, M., \& Feng, J. (2019). Helpfulness of online reviews: Examining review informativeness and classification thresholds by search products and experience products. Decision Support Systems, 124(July), 113099. https://doi.org/10.1016/j.dss.2019.113099

Suprayitno, A., Rochaeni, S., \& Purnomowati, R. (2015). PENGARUH FAKTOR BUDAYA, SOSIAL, PRIBADI, DAN PSIKOLOGI KONSUMEN TERHADAP KEPUTUSAN PEMBELIAN PADA RESTORAN GADO-GADO BOPLO (Studi Kasus: Restoran Gado-Gado Boplo Panglima Polim Jakarta Selatan). AGRIBUSINESS JOURNAL. https://doi.org/10.15408/aj.v9i2.5293

Tariq, M. I., Rafay Nawaz, M., Nawaz, M. M., \& Butt, H. A. (2013). Customer Perceptions about Branding and Purchase Intention: A Study of FMCG in an Emerging Market. $J$. Basic. Appl. Sci. Res.

Tavakoli, R., \& Mura, P. (2015). "Journeys in Second Life" - Iranian Muslim women's behaviour in virtual tourist destinations. In Tourism Management. https://doi.org/10.1016/j.tourman.2014.07.015

Thurstone, L. L. (1928). Attitudes Can Be Measured. American Journal of Sociology. https://doi.org/10.1086/214483

Tsao, W. C., Hsieh, M. T., Shih, L. W., \& Lin, T. M. Y. (2015). Compliance with eWOM: The 

influence of hotel reviews on booking intention from the perspective of consumer conformity. International Journal of Hospitality Management. https://doi.org/10.1016/j.ijhm.2015.01.008

Tussyadiah, I. P., Wang, D., Jung, T. H., \& tom Dieck, M. C. (2018). Virtual reality, presence, and attitude change: Empirical evidence from tourism. Tourism Management. https://doi.org/10.1016/j.tourman.2017.12.003

Tutaj, K., \& van Reijmersdal, E. A. (2012). Effects of online advertising format and persuasion knowledge on audience reactions. Journal of Marketing Communications. https://doi.org/10.1080/13527266.2011.620765

Um, S., \& Crompton, J. L. (1990). Attitude determinants in tourism destination choice. Annals of Tourism Research. https://doi.org/10.1016/0160-7383(90)90008-F

Van Dijk, E., \& Zeelenberg, M. (2003). The Discounting of Ambiguous Information in Economic Decision Making. Journal of Behavioral Decision Making. https://doi.org/10.1002/bdm.450

van Herpen, E., van den Broek, E., van Trijp, H. C. M., \& Yu, T. (2016). Can a virtual supermarket bring realism into the lab? Comparing shopping behavior using virtual and pictorial store representations to behavior in a physical store. Appetite. https://doi.org/10.1016/j.appet.2016.07.033

Van Kerrebroeck, H., Brengman, M., \& Willems, K. (2017a). Escaping the crowd: An experimental study on the impact of a Virtual Reality experience in a shopping mall. Computers in Human Behavior. https://doi.org/10.1016/j.chb.2017.07.019

Van Kerrebroeck, H., Brengman, M., \& Willems, K. (2017b). When brands come to life: experimental research on the vividness effect of Virtual Reality in transformational marketing communications. Virtual Reality. https://doi.org/10.1007/s10055-017-0306-3

Vermeulen, I. E., \& Seegers, D. (2009). Tried and tested: The impact of online hotel reviews on consumer consideration. Tourism Management. https://doi.org/10.1016/j.tourman.2008.04.008

Vincent, V. C., \& Thompson, W. (2002). Assessing community support and sustainability for ecotourism development. Journal of Travel Research. https://doi.org/10.1177/004728702237415

Walsh, K. R., \& Pawlowski, S. D. (2002). Virtual Reality: A Technology in Need of IS Research. Communications of the Association for Information Systems. https://doi.org/10.17705/1cais.00820

Wann, J., \& Mon-Williams, M. (1996). What does virtual reality NEED?: Human factors issues in the design of three-dimensional computer environments. International Journal of Human Computer Studies. https://doi.org/10.1006/ijhc.1996.0035

Waterworth, J. A., Waterworth, E. L., Riva, G., \& Mantovani, F. (2015). Presence: Form, content and consciousness. In Immersed in Media: Telepresence Theory, Measurement and Technology. https://doi.org/10.1007/978-3-319-10190-3_3

Weibel, D., Schmutz, J., Pahud, O., \& Wissmath, B. (2015). Measuring spatial presence: Introducing and validating the pictorial presence SAM. Presence: Teleoperators and Virtual Environments. https://doi.org/10.1162/PRES_a_00214

Williams, A. (2006). Tourism and hospitality marketing: fantasy, feeling and fun. In International Journal of Contemporary Hospitality Management. 
Williams, P., \& Hobson, J. P. (1995). Virtual reality and tourism: fact or fantasy? Tourism Management. https://doi.org/10.1016/0261-5177(95)00050-X

Wilson, A., Murphy, H., \& Fierro, J. C. (2012). Hospitality and Travel: The Nature and Implications of User-Generated Content. In Cornell Hospitality Quarterly. https://doi.org/10.1177/1938965512449317

Wirth, W., Hartmann, T., Böcking, S., Vorderer, P., Klimmt, C., Schramm, H., Saari, T., Laarni, J., Ravaja, N., Gouveia, F. R., Biocca, F., Sacau, A., Jäncke, L., Baumgartner, T., \& Jäncke, P. (2007). A process model of the formation of spatial presence experiences. Media Psychology. https://doi.org/10.1080/15213260701283079

Wu, P. F. (2013). In search of negativity bias: An empirical study of perceived helpfulness of online reviews. Psychology and Marketing. https://doi.org/10.1002/mar.20660

Xu, P., Chen, L., \& Santhanam, R. (2015). Will video be the next generation of e-commerce product reviews? Presentation format and the role of product type. Decision Support Systems. https://doi.org/10.1016/j.dss.2015.03.001

Xue, F., \& Zhou, P. (2011). The effects of product involvement and prior experience on chinese consumers' responses to online word of mouth. Journal of International Consumer Marketing. https://doi.org/10.1080/08961530.2011.524576

Yang, J., \& Mai, E. S. (2010). Experiential goods with network externalities effects: An empirical study of online rating system. Journal of Business Research. https://doi.org/10.1016/j.jbusres.2009.04.029

Yang, S. B., Hlee, S., Lee, J., \& Koo, C. (2017). An empirical examination of online restaurant reviews on Yelp.com: A dual coding theory perspective. International Journal of Contemporary Hospitality Management. https://doi.org/10.1108/IJCHM-11-2015-0643

Ye, Q., Law, R., \& Gu, B. (2009). The impact of online user reviews on hotel room sales. International Journal of Hospitality Management. https://doi.org/10.1016/j.ijhm.2008.06.011

Ye, Q., Law, R., Gu, B., \& Chen, W. (2011). The influence of user-generated content on traveler behavior: An empirical investigation on the effects of e-word-of-mouth to hotel online bookings. Computers in Human Behavior. https://doi.org/10.1016/j.chb.2010.04.014

Zahorik, P., \& Jenison, R. L. (1998). Presence as being-in-the-world. Presence: Teleoperators and Virtual Environments, 7(1), 78-89. https://doi.org/10.1162/105474698565541

Zeng, G., Cao, X., Lin, Z., \& Xiao, S. H. (2020). When online reviews meet virtual reality: Effects on consumer hotel booking. Annals of Tourism Research, 81(December 2019), 1-12. https://doi.org/10.1016/j.annals.2020.102860

Zhang, Z., Ye, Q., Law, R., \& Li, Y. (2010). The impact of e-word-of-mouth on the online popularity of restaurants: A comparison of consumer reviews and editor reviews. International Journal of Hospitality Management. https://doi.org/10.1016/j.ijhm.2010.02.002

Zhu, F., \& Zhang, X. (2010). Impact of online consumer reviews on Sales: The moderating role of product and consumer characteristics. In Journal of Marketing. https://doi.org/10.1509/jmkg.74.2.133 